\title{
PENGARUH MEDIA AUDIO VISUAL TERHADAP KEMAMPUAN MENGINGAT GERAKAN PADA PENARI DI SANGGAR TARI DHARMA PRAGINA DEWI.
}

\author{
Putu Muslika Dewi ${ }^{1}$,Desy Arisandy ${ }^{2}$ \\ MahasiswaUniversitas Bina Darma ${ }^{1}$, Dosen Universitas Bina Darma \\ Jalan Jenderal Ahmad Yani No.3 Palembang \\ Sur-el : putumustikadewi438@gmail.com ${ }^{1}$, desi.arisandy@binadarma.ac.id ${ }^{2}$
}

\begin{abstract}
This study aimed to explore the influence of audiovisual media to memory in dancer at dance studio dharma pragina dewi. Hyphothesis in there are influence of audiovisual media to memory in dancer at dance studio dharma pragina dewi. This research use observation checklist the ability remember to movement of galang bulan dance. This research use experiment methods. The sample of this study were dancer of studio dance dharma pragina dewi which numbered 20 people with data analisys independent sample t-test techniques. The results of computer analysis of research data using SPSS 20.0 for windows, obtained value the results of independent sample ttest $t=-7.415$ and $p=0,000(p<0.05)$. this suggest that the hyphotesis is accepted. The result of this analysis can be stated that there is the effect of audiovisual media is significant to memory in dancer at dance studio dharma pragina dewi.
\end{abstract}

Keywords: audiovisual media, memory, observation checklist

\begin{abstract}
Abstrak: Penelitian ini bertujuan untuk mengetahui adanya pengaruh media audio visual terhadap kemampuan mengingat gerakan pada penari di sanggar tari dharma pragina dewi. Hipotesis awal yang diajukan dalam penelitian ini adalah ada pengaruh media audio visual terhadap kemampuan mengingat gerakan pada penari di sanggar tari dharma pragina dewi. Penelitian ini menggunakan observasi cek list kemampuan mengingat gerakan. Penelitian ini menggunakan metode eksperimen. Sample dalam penelitian ini adalah 20 orang penari sanggar tari dharma pragina dewi dengan teknik analisis data independent sample t- test. Hasil analisis data penelitian dengan menggunakan program SPSS 20.0 for windows, hasil dari uji independent sample t test diperoleh nilai $t=-7.415$ dan $p=0,000(p<0,05)$. Hal ini menunjukkan bahwa hipotesis diterima. Hasil analisis tersebut dapat dikemukakan bahwa ada pengaruh pemberian media audio visual yang signifikan terhadap kemampuan mengingat gerakan pada penari di sanggar tari dharma pragina dewi.
\end{abstract}

Kata kunci: media audio visual, kemampuan mengingat, observasi ceklis

\section{PENDAHULUAN}

Menari merupakan suatu seni gerak anggota tubuh dengan masing-masing gaya yang bermacam-macam diikuti dengan musik. Biasanya ditampilkan dalam acara perpisahan sekolah, pesta atau acara lainnya. Menari juga merupakan seni yang menarik dipandang seperti goyang tubuh, gerak tangan, gerak pinggul, dan gerak seluruh anggota tubuh.
Kegiatan menari disukai oleh berbagai kalangan mulai dari anak-anak sampai dengan dewasa. Kemampuan menari biasanya diperoleh melalui bakat dan minat serta latihan di sebuah sanggar tari ataupun secara otodidak (Rahma, 2010).

Seorang penari mempunyai tugas tidak hanya melakukan gerak pada seluruh anggota tubuh dan mengkomunikasikan gagasan dalam 
tari, namun tugas utamanya adalah memberikan nyawa kepada tari, melalui bahasa tubuhnya dan melalui ekspresinya, sehingga segala pesan yang terkandung dalam tari dapat juga dihayati, dipahami dan dapat diinterpretasikan oleh penontonnya. Untuk sampai kepada kemampuan penjiwaan dalam menari, ada beberapa kemampuan dasar yang harus dimiliki oleh seorang penari, yaitu: a) Wiraga, memiliki keterampilan teknis gerak, mencakup kemampuan menghafal urutan gerak, kemampuan olah tubuh, kemampuan mentaati gaya tari dan kelenturan, b) Wirama, memiliki kepekaan musikal, yaitu kepekaan dalam menyelaraskan ritme gerak tubuh dengan ritme musiknya atau menyelaraskan ritme gerak dengan penari lainnya, c) Wirasa, mampu menghayati dan mengekpresikan karakter peran dan karakter tari (Handoko, 2014). Oleh karena itu kemampuan mengingat dalam menari sangat diperlukan dimana seorang penari harus mampu menerima, menyimpan dan mengeluarkan kembali informasi-informasi mengenai tarian yang dipelajarinya. Untuk menunjang bakat-bakat yang dimiliki oleh seorang dalam hal seni tari biasanya seorang penari baik anak-anak sampai dengan dewasa meningkatkan kemampuan mereka dengan belajar menari melalui media maupun ikut dalam sebuah sanggar tari.

Sanggar tari merupakan wadah untuk melakukan berbagai aktivitas seni tari bersama dengan para anggotanya, didalamnya meliputi kegiatan belajar mengajar tari, berkarya seni dan bertukar pikiran mengenai segala hal yang berhubungan dengan karya seni. Keberadaan sanggar tari salah satunya adalah untuk mempertahankan tari-tari tradisi maupun tari klasik disamping mengembangkan bentuk-bentuk tari modern, tari kontemporer maupun tari kreasi baru. Masuknya budaya asing dapat dibentuk dengan penanaman kecintaan pada kebudayaan milik bangsa, salah satunya dengan melakukan kegiatan berkesenian (Hadie, 2015). Di dalam sanggar media pembelajaran yang digunakan oleh seorang penari biasanya melibatkan guru atau pelatih secara langsung maupun menggunakan media pembelajaran yang lain. Guru berupaya untuk menampilkan rangsangan (stimulus) yang dapat diproses dengan berbagai indera. Semakin banyak alat indera yang digunakan untuk menerima dan mengolah informasi, semakin besar kemungkinan informasi tersebut dimengerti dan dipertahankan dalam ingatan (Arsyad, 2016).

Menurut Levie \& Levie (Arsyad, 2016) menyimpulkan bahwa stimulus visual membuahkan hasil belajar yang lebih baik untuk tugas-tugas seperti mengingat, mengenali, mengingat kembali dan menghubungkan fakta-fakta dan konsep. Menurut Susila dan Riyana (2009), alat bantu visual berupa sarana yang dapat memberikan 
pengalaman visual kepada siswa antara lain mendorong motivasi belajar, memperjelas dan mempermudah konsep yang abstrak dan mempertinggi daya serap atau retensi belajar.

Menurut Bastable (2002) media audiovisual mendukung dan memperkaya proses pendidikan dengan menstimulasi indra penglihatan dan pendengaran peserta didik, menambah variasi pada pengalaman belajar mengajar dan menanamkan ingatan visual yang terbukti lebih permanen dari pada ingatan audiktif. Namun baru akhir-akhir ini teknologi memungkinkan penerapan alat-alat audio visual untuk tujuan pengajaran dan pembelajaran. Alat bantu ini dapat mempengaruhi tiga domain pembelajaran dengan meningkatkan pengembangan kognitif, mempengaruhi perubahan sikap dan ikut membangun ketrampilan psikomotorik. Audiovisual mampu meningkatkan retensi informasi dnegan menggabungkan apa yang di dengar dan apa yang dilihat. Di bawah ini ada beberapa penelitian yang berkaitan dengan media audio visual diantaranya adalah penelitian tentang media dan emotional word yang berkaitan dengan kemampuan mengingat.

Hasil penelitian tersebut menyimpulkan bahwa ada pengaruh emotional words terhadap kemampuan mengingat pada kelompok media audio visual (Herdiansyah dkk, 2014). Dalam penelitian tersebut kemampuan mengingat akan meningkat apabila informasi diberikan melalui media audio visual bukan hanya dari media audio atau visual saja.

Penelitian ini bertujuan untuk mengetahui pengaruh media audio visual terhadap kemampuan mengingat gerakan pada penari sanggar tari dharma pragina dewi di makarti jaya. 


\section{METODOLOGI PENELITIAN}

Identifikasi Variabel Penelitian, terdiri dari Variabel Terikat (Dependent Variable): Kemampuan Mengingat Gerakan, Variabel Bebas (Independent Variable): Media audio visual . Variabel Kontrol (Control Variable) Variabel kontrol adalah variabel yang dikendalikan oleh peneliti karena variabelvariabel ini diduga akan mempengaruhi hasil penelitian.

Kemampuan mengingat atau memori merupakan proses untuk menerima, menyimpan, dan menimbulkan kembali infomasi-informasi yang telah diterima oleh penari sebelumnya. Pengukuran kemampuan mengingat pada penari dilakukan dengan menggunakan media audio visual, lalu menampilkan tari galang bulan dengan durasi 11 menit 29 detik. Pengukuran dilakukan dengan mengisi skor angka di lembar observasi checklist kemampuan mengingat gerakan yang diisi oleh peneliti dan guru/ pelatih tari yaitu sebelum dan sesudah menggunakan media audio visual.

Media audio visual adalah media pembelajaran elektronik yang bersama-sama menampilkan audiktif (pendengaran) dan visual (pengelihatan) sebagai sumber belajar dan penyalur informasi. Media yang digunakan berbentuk audiovisual gerak yaitu dengan menggunakan ved. Pengukuran dengan media audio visual dilakukan bersamaan dengan pengukuran kemampuan mengingat yaitu dengan mengisi lembar observasi checklist yang dilakukan oleh peneliti dan guru/pelatih tari.

Hipotesis dalam penelitian ini adalah ada pengaruh media audio visual terhadap kemampuan mengingat gerakan pada penari di Sanggar Tari Dharma Pragina Dewi

Populasi dalam penelitian ini adalah penari di sanggar tari dharma pragina dewi sebanyak 45 orang, sebanyak 10 orang tidak dijadikan populasi karena masih pada usia anak-anak, jadi fokus penelitian ini dilakukan pada 35 orang anggota. Sampel tryout alat ukur sebanyak 15 orang dan penelitian sebanyak 20 orang yang akan dibagi menjadi 10 orang kelompok eksperimen dan 10 orang kelompok kontrol.

Metode pengumpulan data yaitu : Metode Observasi Merupakan metode pengumpulan data dengan cara mengamati perilaku subjek.. Metode Wawancara merupakan metode pengumpulan data dengan cara mewawancarai penari yang latihan dengan menggunakan media audio visual dan yang tidak menggunakan media audio visual.

Alat ukur untuk mengukur kemampuan mengingat yang digunakan adalah lembar observasi checklist. Observasi dilakukan dengan memberikan tanda checklist pada lembar observasi yaitu pada kelompok eksperimen dan kelompok kontrol. 
Hal yang akan diobservasi dalam penelitian ini adalah gerakan yang ditampilkan oleh penari. Observasi dilakukan oleh dua orang observer, agar peneliti dapat membandingkan hasil observasi antara observer satu dan observer dua sehingga dapat mengurangi adanya penilaian subyektif saat observasi. Observer lain tersebut yaitu guru/pelatih di sanggar tari dharma pragina dewi. Untuk keperluan analisis kuantitatif, maka penilaian diberi skor atau nilai yang telah ditentukan oleh pihak sanggar yaitu nilai satu sampai dengan lima, nilai tersebut diberikan pada masingmasing gerakan tarian sesuai dengan ketentuan gerakan.

Desain yang digunakan dalam penelitian ini adalah dua kelompok (two group) kelompok eksperimen dan kelompok kontrol. Pada penelitian dua kelompok ini, desain eksperimen yang diberikan adalah non randomized pretest-posttest control group design. Desain ini dilakukan pretest dan posttest.

Salah satu masalah utama dalam kegiatan penelitian sosial ini adalah cara memperoleh data yang akurat dan objektif. Hal ini menjadi sangat penting artinya disebabkan kesimpulan penelitian hanya akan dapat dipercaya apabila didasarkan pada informasi yang juga dapat dipercaya (Azwar, 2004).
Uji validitas dalam penelitian ini menggunakan uji validitas isi. Menurut Azwar, (2012) keputusan akal sehat mengenai keselarasan atau relevansi aitem dengan tujuan ukur skala tidak dapat didasarkan hanya pada penilaian penulis soal sendiri tapi juga memerlukan kesepakatan penilaian dari beberapa penilai yang kompeten (expert judgement). Uji validitas dalam penelitian ini menggunakan koefisien validitas isi Aikens's $V$. Aiken's (Azwar, 2012) telah merumuskan formula aiken's V untuk menghitung content-validity coefficient yang didasarkan pada hasil penilaian panel ahli sebanyak $\mathrm{n}$ orang terhadap suatu aitem mengenai sejauh mana aitem tersebut mewakili konstruk yang diukur. Penilaian dilakukan dengan cara memberikan angka antara 1 (yaitu sangat tidak mewakili atau sangat tidak relevan) sampai dengan 5 (yaitu sangat mewakili atau sangat relevan). Rentan angka $\mathrm{V}$ yang mungkin diperoleh adalah antara 0 sampai dengan 1,00 dapat diintepretasikan sebagai koefisien yang tinggi.

Menurut Azwar (2012) salah satu ciri instrument ukur yang berkualitas baik adalah reliabel (reliable) yaitu mampu menghasilkan skor yang cermat dengan eror pengukuran kecil. Pengertian reliabilitas mengacu kepada kepercayaan atau konsistensi hasil ukur, yang mengandung makna seberapa tinggi kecermatan 
pengukuran. Koefisien reliabilitas berada dalam rentang angka 0 sampai 1,00. Sekalipun bila koefisien reliabilitas semakin tinggi mendekati angka 1,00 bearti pengukuran semakin reliabel. Penelitian ini akan dilakukan pengukuran reliabilitas dengan menggunakan Alpha Cronbach.

Analisis data yang digunakan dalam penelitian ini adalah analisis statistik. Sebelum dilakukan uji hipotesis. Terlebih dahulu dilakukan uji asumsi yaitu uji normalitas dan uji homogenitas. Untuk menguji hipotesis penelitian, penulis menggunakan teknik analisis uji $\mathrm{t}$ yaitu independent sample t-test.

\section{HASIL DAN PEMBAHASAN}

Uji validitas pada masing-masing aitem dalam observasi cheklist yang dilakukan penilaian oleh empat orang ahli diperoleh hasil yaitu, item satu yaitu 0.75 , item dua yaitu 0.687, item tiga 0.687 . Berdasarkan uji koefisien validitas isi ainken's tersebut dapat disimpulkan bahwa seluruh item dalam observasi cheklist memiliki koefisien validitas isi yang tinggi. Berdasarkan hasil try out yang dilakukan pada 15 orang diperoleh hasil uji validitas pada item 1 yaitu paling rendah 0.25 dan yang paling tinggi yaitu 0.75 , selanjutnya pada item 2 diperoleh hasil uji validitas yang paling rendah yaitu 0.562 dan yang tertinggi adalah 1, sedangkan pada item 3 diperoleh hasil uji validitas yang paling rendah yaitu
0.687 dan yang paling tertinggi adalah 1 . Dengan demikian dapat disimpulkan bahwa setiap aitem dalam observasi checklist kemampuan mengingat gerakan berkisar antara 0 sampai dengan 1,00 sehingga setiap item dalam lembar observasi kemampuan mengingat gerakan memiliki koefisien yang tinggi.

Uji reliabilitas pada observasi checklist menunjukkan nilai reliabilitas alpha sebesar 0,933. Dengan demikian observasi kemampuan mengingat gerakan dapat dikatakan memiliki nilai reliabilitas yang tinggi dan layak karena nilai reliabilitas tersebut bergerak antara 0,00 sampai dengan 1,00 sehingga dapat dikatakan layak (Azwar, 2012).

\section{A. Hasil Uji asumsi}

Berdasarkan analisis uji normalitas data dengan menggunakan kolmogorov-smirnov, hasil untuk KK adalah $\mathrm{KS}-\mathrm{Z}=1,123$ dan $\mathrm{p}$ $=0,160$ sehingga $\mathrm{p}>0,05$, sedangkan hasil $\mathrm{KE}$ adalah KS-Z $=0,520$ dan $\mathrm{p}=0,950$ sehingga $\mathrm{p}>0,05$, maka data $\mathrm{KK}$ dan $\mathrm{KE}$ dapat dikatakan terdistribusi normal.

Berdasarkan uji homogenitas hasil yang diperoleh adalah $\mathrm{F}=0,503$ sedangkan sig. $=$ $0,487$ ( $>00,05)$. hal ini berarti varians antar kelompok-kelompok yang dibandingkan tidak berbeda: artinya homogen

\section{B. Hasil uji hipotesis}


Hasil uji hipotesis dilakukan pada hasil skor yang diperoleh kelompok kontrol dan kelompok eksperimen. Analisis statistik yang digunakan dalam penelitian ini adalah Independent Sample T-Test. Pada data pretest yang diperoleh adalah menunjukkan nilai $\mathrm{t}=-0,855,(\mathrm{p}=0,404 ; \mathrm{p}>0,05)$, hal ini menunjukkan bahwa tidak ada perbedaan antara kelompok kontrol dan kelompok eksperimen sehingga tidak ada pengaruh media audio visual pada penari Sanggar Tari Dharma Pragina Dewi di Makarti Jaya, pretest dilakukan untuk melihat kemampuan awal setiap subjek sebelum diberikan treatmen, sedangkan pada data posttest diperoleh hasil nilai $\mathrm{t}=-7,415,(\mathrm{p}=0,000$; $\mathrm{p}<0,05$ ). Oleh karena itu, hipotesis null (Ho) ditolak, dan hipotesis (Ha) diterima pada taraf signifikansi 0,05 dengan demikian dapat disimpulkan bahwa ada pengaruh media audio visual terhadap kemampuan mengingat gerakan pada penari Sanggar Tari Dharma Pragina Dewi di Makarti Jaya.

\section{Pembahasan}

Uji asumsi yang telah dikelola menggunakan SPSS 20.0 terlihat bahwa sebaran data pada kelompok kontrol dan kelompok eksperimen dalam penelitian adalah normal. Hasil dilihat dari nilai p pada kelompok kontrol yaitu $\mathrm{p}=0,160$ sehingga p> 0,05 dan pada kelompok eksperimen yaitu $p=0,950$ sehingga $p>0,05$, maka data
KK dan KE dapat dikatakan terdistribusi normal.

Uji asumsi ini juga memperlihatkan homogenitas data pada kelompok kontrol dan kelompok eksperimen dimana hasil yang diperoleh adalah $\mathrm{F}=0,503$ sedangkan sig. $=$ $0,487$ ( $p>0,05)$. hal ini berarti varians antar kelompok-kelompok yang dibandingkan tidak berbeda: artinya homogen.

Berdasarkan perhitungan statistik yang dilakukan untuk membuktikan, bahwa terdapat pengaruh media audio visual terhadap kemampuan mengingat gerakan pada penari di sanggar tari dharma pragina dewi. Analisis dilakukan dengan menggunakan uji t independent sample t-test, yang hasilnya menunjukkan ada penerimaan terhadap hipotesis yang diajukan. Hasil tersebut dapat dilihat dari hasil pada saat posttest dengan nilai $\mathrm{t}=-7,415,(\mathrm{p}=0,000$; $\mathrm{p}<0,05)$. Oleh karena itu, hipotesis null (Ho) ditolak, dan hipotesis (Ha) diterima pada taraf signifikansi 0,05 hal ini menunjukkan bahwa bahwa ada pengaruh media audio visual yang signifikan terhadap kemampuan mengingat gerakan pada penari di Sanggar Tari Dharma Pragina Dewi.

Ingatan ialah kekuatan jiwa untuk menerima, menyimpan, dan mereproduksikan kesan-kesan. Dengan adanya kemampuan untuk mengingat pada manusia, bearti ada suatu indikasi bahwa 
manusia mampu untuk menyimpan dan menimbulkan kembali sesuatu yang pernah dialami. Namun tidak bearti bahwa semua yang pernah dialami itu akan tetap tinggal seluruhnya dalam ingatan, oleh karena ingatan merupakan kemampuan yang terbatas (Ahmadi, 2009). Kemampuan dalam mengingat gerakan pada penari di Sanggar Tari Pragina Dewi terlihat berbeda ketika latihan menggunakan media audio visual dan latihan dengan arahan langsung dari pelatih tanpa menggunakan media audio visual. Penari yang latihan dengan guru atau tanpa media audio visual terlihat cukup lama dalam menguasai gerakan dan lebih sering melakukan kesalahan pada gerakan yang telah dipelajari sebelumnya.

Kemampuan mengingat pada penari terlihat cukup baik ketika latihan menari dengan menggunakan media audio visual, karena dengan menggunakan media penari dapat secara langsung mempelajari gerakan tarian dan mendengarkan musik iringan tari secara bersamaan sehingga mereka dengan mudah mengingat setiap gerakan yang dipelajari sebelumnya, sedangkan ketika penari latihan hanya dengan arahan dari guru atau pelatih, penari terlihat kesulitan menguasai gerakan dengan detail, sering terjadi kesalahan yang dilakukan berulangulang dan mengingat gerakan yang telah dipelajari pun cukup lama karena mereka harus menyesuaikan kembali antara gerakan dan musik. Sehingga dengan menggunakan media audio visual menimbulkan semangat yang tinggi pada penari dalam mempelajari tari-tarian dengan lebih baik dan cepat. Para ahli memandang ingatan sebagai hubungan antara pengalaman dengan masa lampau. Dengan adanya kemampuan mengingat pada manusia, hal ini menunjukkan bahwa manusia mampu menerima, menyimpan, dan menimbulkan kembali pengalamanpengalaman yang dialaminya. Apa yang pernah dialami manusia tidak seluruhnya hilang, tetapi disimpan didalam jiwanya dan apabila diperlukan hal-hal yang disimpan itu dapat ditimbulkan kembali dalam kesadaran, (Fitriyah \& Jauhar, 2014). Penari Sanggar Tari Dharma Pragina Dewi menggunakan media audio visual dalam proses latihan merupakan salah satu pencapaian yang positif bagi penari untuk lebih meningkatkan kemampuan mengingat mereka dalam mempelajari gerakan tarian.

Media audiovisual mendukung dan memperkaya proses pendidikan dengan menstimulasi indra penglihatan dan pendengaran peserta didik, menambah variasi pada pengalaman belajar mengajar dan menanamkan ingatan visual yang terbukti lebih permanen dari pada ingatan audiktif. Namun baru akhir-akhir ini teknologi memungkinkan penerapan alat-alat audio visual untuk tujuan pengajaran dan pembelajaran. Alat bantu ini dapat 
mempengaruhi tiga domain pembelajaran dengan meningkatkan pengembangan kognitif, mempengaruhi perubahan sikap dan ikut membangun ketrampilan psikomotorik. Audiovisual mampu meningkatkan retensi informasi dengan menggabungkan apa yang di dengar dan apa yang dilihat (Bastable, 2002).

Media sangat bermanfaat khususnya dalam proses pembelajaran. Manfaat media yaitu, a) meningkatkan rasa saling pengertian dan simpati dalam kelas; b) membuahkan perubahan signifikan tingkah laku siswa; c) menunjukkan hubungan antara mata pelajaran dan kebutuhan serta minat siswa dengan meningkatnya motivasi belajar siswa; d) membawa kesegaran dan variasi bagi pengalamn belajar siswa; e) membuat hasil belajar lebih bermakna bagi berbagai kemampuan siswa; f) mendorong pemanfaatan yang bermakna dari mata pelajaran dengan jalan melibatkan imajinasi dan partisipasi aktif yang mengakibatkan meningkatnya hasil belajar; g) memberikan umpan balik yang diperlukan, yang dapat membantu siswa menemukan seberapa banyak materi yang telah mereka pelajari; h) melengkapi pengalaman yang kaya dengan pengalaman itu, konsep-konsep yang bermakna dapat dikembangkan; i) memperluas wawasan dan pengalaman siswa yang mencerminkan pembelajaran yang nonverbalistik; j) meyakinkan diri bahwa urutan dan kejelasan pikiran yang siswa butuhkan, jika mereka membangun struktur konsep dan system gagasan yang bermakna, (Arsyad, 2016).

Media audio visual memiliki kontribusi yang besar dalam proses belajar terutama latihan menari. Penggunaan media audio visual dapat memudahkan penari dan guru serta lebih menghemat waktu dalam latihan. Dengan menggunakan media audio visual penari dapat secara langsung mempelajari gerakan dan musik bahkan bisa diawasi langsung oleh guru atau pelatihnya. Selain itu guru atau pelatih dapat dengan leluasa memperhatikan dan mengawasi gerakangerakan yang telah dipejari oleh penari. Guru atau pelatih juga bisa mengarahkan penari untuk menciptakan kreatifitas dalam gerakan tarian tanpa menghilangkan unsur asli gerakan tarian tersebut.

Hal tersebut sejalan dengan hasil wawancara penulis terhadap salah satu guru atau pelatih di Sanggar Tari Dharma Pragina Dewi yang mengajar untuk penari yang menggunakan media audio visual, bahwa memang media audio visual sangat membantu dalam proses belajar mengajar di sanggar tersebut, karena kekurangan tenaga pengajar di sanggar tersebut terkadang membuat para guru atau pelatihnya kewalahan selain itu media audio visual juga menjadikan para penari lebih mandiri dalam 
latihan dan tidak selalu bergantung pada kehadiran guru atau pelatih.

Levie \& Lentz (Arsyad, 2016) mengungkapkan empat fungsi media pembelajaran khususnya media visual yaitu: a) fungsi atensi, menarik dan mengarahkan perhatian siswa untuk berkonsentrasi kepada isi pelajaran yang berkaitan dengan makna visual yang ditampilkan atau menyertai teks materi pelajaran, b) fungsi afektif, gambar atau lambing visual dapat menggugah emosi dan sikap siswa, misalnya informasi yang menyangkut masalah sosial atau ras, c) fungsi kognitif, media visual terlihat dari temuan-temuan penelitian yang mengungkapkan bahwa lambang visual atau gambar memperlancar pencapaian tujuan untuk memahami dan mengingat informasi atau pesan yang terkandung dalam gambar, d) fungsi kompensatoris, media pembelajaran terlihat dari hasil penelitian bahwa media visual yang memberikan konteks untuk memahami teks membantu siswa yang lemah dalam membaca untuk mengorganisasikan informasi dalam teks dan mengingatnya kembali.

Berdasarkan hasil penelitian yang telah dilakukan kepada subjek pengaruh media audio visual berpengaruh terhadap kemampuan mengingat gerakan penari, hal ini terlihat dari reaksi dan respon subjek saat latihan dengan media audio visual dan latihan dengan arahan dari guru tanpa menggunakan media. Dengan arahan dari guru subjek terlihat cepat bosan dan kadang kala tidak mengikuti dengan baik setiap gerakan yang dijelaskan oleh guru atau pelatihnya, tetapi dengan menggunakan media audio visual subjek terlihat sangat bersemangat dengan terus mengikuti gerakan yang ditampilkan oleh media. Selain itu subjek juga dapat lebih cepat dalam mengingat gerakan dan tidak kebingungan saat diminta untuk mempraktikan kembali gerakan yang telah dipelajari sebelumnya.

Hal ini juga didukung dari skor data posttest kemampuan mengingat gerakan, dimana ada perbedaan skor pada kelompok kontrol yaitu kelompok yang latihan dengan guru atau pelatih tanpa menggunakan media dan kelompok eksperimen yaitu kelompok yang latihan dengan menggunakan media audio visual. Hal ini berkaitan dengan penelitian yang dilakukan oleh (Herdiansyah dkk, 2014). Hasil penelitian tersebut menyimpulkan kemampuan mengingat akan meningkat apabila informasi diberikan melalui media audio visual bukan hanya dari media audio atau visual saja. Salah satu cara untuk meningkatkan kemampuan mengingat dalam belajar yaitu dengan menggunakan media pembelajaran seperti media audio visual untuk menunjang proses belajar atau latihan menari dengan baik.

Mais (2016) menjelaskan bahwa media memiliki nilai-nilai praktis berupa 
kemampuan yaitu: a) konkritisasi konsep yang abstrak, b) membawa pesan dari objek yang berbahaya dan sukar atau bahkan tidak mungkin dibawa kedalam lingkungan belajar, c) menampilkan objek yang terlalu besar, d) menampilkan objek yang tidak dapat diamati oleh mata telanjang, e) mengamati gerakan yang terlalu cepat, f) memungkinkan siswa berinteraksi langsung dengan lingkungan, g) memungkinkan pengamatan dan persepsi yang seragam bagi pengalaman belajar siswa, h) membangkitkan motivasi siswa, i) memberi kesan, perhatian individual bgi anggota kelompok belajar, j) menyajikan informasi belajar secara konsisten dan dapat diulang maupun disimpan menurut kebutuhan.

Berdasarkan uraian dan hasil analisis data di atas, peneliti menyimpulkan bahwa hipotesis yang diajukan oleh peneliti yaitu ada pengaruh media audio visual terhadap kemampuan mengingat gerakan pada penari di sanggar tari dharma pragina dewi dalam penelitian ini diterima. Adapun bunyi dari hipotesis penelitian ini berdasarkan hasil analisis data yang telah dilakukan adalah ada pengaruh media audio visual yang signifikan terhadap kemampuan mengingat gerakan pada penari sanggar tari dharma pragina dewi di makarti jaya.

\section{SIMPULAN}

Berdasarkan hasil penelitian yang diperoleh, maka dapat dibuat kesimpulan bahwa terdapat pengaruh media audio visual yang signifikan terhadap kemampuan mengingat gerakan pada penari sanggar tari dharma pragina dewi di makarti jaya dengan nilai $\mathrm{t}=-7,415$. 


\section{DAFTAR RUJUKAN}

Ahmadi, A. 2009. Psikologi umum. Jakarta: Rineka Cipta

Arsyad, A. 2016. Media Pembelajaran. Jakarta: PT Raja Grafinfo Persada

Azwar, S. 2012. Penyusunan skala psikologi. Yogyakarta: Pustaka Pelajar

Bastable, S, B. 2002. Perawat Sebagai Pendidik: Pinsip-Prinsip Pengajaran dan Pembelajaran. Jakarta: Penerbit Buku Kedokteran EGC

Chussurur, M., Hidayat, T., Agustin, R,W. 2011. Pengaruh Pemberian Cerita Melalui Media Audio Visual Terhadap Recall Memory Pada AnakAnak Kelas V Sekolah Dasar Takmirul Islam Surakarta. Jurnal Psikologi Fakultas Kedokteran. Universitas Sebelas Maret Surakarta

Dewi, I, A, G, B., Indrawati, K, R. 2014. Perilaku Mencatat dan Kemampuan Memori pada Proses Belajar. Jurnal Psikologi Udayana 2014, Vol. 1, No. 2, 241-250

Djamarah, S.B., Zain, A. 2013. Strategi belajar mengajar. Jakarta: Rineka Cipta

Fedotova, O., latuna, V. 2015. Experimental Study of Audiovisual Approach in a Course on the Psychology of Creativity. Procedia - Social and Behavioral Sciences $191 \quad$ (2015) 1054 -1061. Southern Federal University, Faculty of Psychology, Nagibina Street

Fitriyah, L., Jauhar, M. 2014. Pengantar Psikologi Umum. Jakarta: Prestasi Pustaka Raya

Fudyartanta, K. 2011. Psikologi Umum 1\&2. Yogyakarta: Pustaka Pelajar
Hadie, H, R. (2015). Pengelolaan Seni Di Bale Seni Ciwasiat Pandeglang Banten. (skripsi, tidak diterbitkan). Fakultas Pendidikan Seni dan Desain. Universitas Pendidikan Indonesia

Handoko. (24 Januari 2014). Macam-macam tarian di indonesia. Diakses dari: http://macam-macam-tariandaerah.blogspot.com/2014/01/penjiwa an-merupakan-kemampuandasar.html?m=1 pada tanggal 2 maret 2018 jam 19.00 WIB

Herdiansyah, L, I., Mokodenseho, T, I., Hidayatullah, A, P., \& Ridfah, A. (2014). Efektivitas media dan emotional words terhadap kemampuan mengingat. Jurnal psikologi karakter. Vol 1, Nomor. 2

Hurlock, E, B. 1980. Psikologi Perkembangan. Jakarta: Erlangga

Iriansyah. (Februari 2017) Manfaat Audio Visual. Diakses Dari: https://alasakmana.blogspot.com/201 7/02/manfaat-audio-visual.html?m=1. Pada tanggal 25 maret 2018, jam 14.00 WIB

Joewana, S., Margiyani, L., Padmohoedojo, L, G., Widayat, E., Ajisukusmo, C, R,P., Tambunan, M. 2001. NARKOBA petunjuk praktis bagi keluarga untuk mencegah penyalahgunaan narkoba. Yogyakarta: Media Pressindo

Khasanah, I., Widyana, R., \& Kusumawardani, I, R. 2012. Efektivitas pelatihan imageri terhadap peningkatan kemampuan mengingat pada siswa sekolah menengah pertama. Fakultas psikologi universitas mercu buana

Ling, J., Chatling, J. 2012. Psikologi kognitif. Jakarta: Erlangga 
Mais, Asrorul. 2016. Media Pembelajaran Anak Berkebutuhan Khusus. Jember: CV Pustaka Abadi

Mahmud. 2010. Psikologi Pendidikan. Bandung: Pustaka Setia

Malik, Imam. 2016. Pengantar Psikologi Umum. Yogyakarta: Kalimedia

Middlebrooks, C, D., Murayama, K., \& Castel, A, D. 2017. Test Expectancy and Memory for Important Information. Journal of Experimental Psychology: Learning, Memory, and Cognition. American Psychological Association

Nuswantari, W. Astuti, T, P. 2015. Pengaruh pemberian lagu anak-anak terhadap perilaku prososial siswa taman kanakkanak. Jurnal empati, oktober 2015, volume 4(4), 103

Papalia, D.E., Olds, S.W., Fieldman, R.D. 2011. Human Development, edisi kesembilan. Jakarta: Salemba Humanika

Prayana, A, A, N, W., Adiputra, I, N., \& Tianing, N, W. pelatihan tari galang bulan meningkatkan kebugaran fisik pada pelajar SMP di yayasan perguruan Kristen harapan Denpasar. Majalah ilmiah fisioterap. Volume 2, nomor 1, 9-13

Rahma, R. (2010, oktober 25). Artikel: menari. Diakses dari http://rickyrahma.blogspot.co.id/2010 /10/artikel-menari.html?m=1. Pada tanggal 3 maret 2018, jam 17.45 WIB

Richard, A., M., Hollingworth, H. 2012. The Strategic Retention of Task Relevant Objects in Visual Working Memory. Journal of Experimental Psychology: Learning, Memory, and Cognition. American Psychological Association

Satrianawati. 2018. Media dan Sumber Belajar. Yogyakarta: Deepublish
Sayidiman, 2012. Penggunaan media audio visual dalam merangsang minat mahasiswa terhadap mata kuliah seni tari. Publikasi, Volume II No. 1 Februari-Mei 2012, 41-41

Schwan, S., Cress, U. 2017. The Psychology Of Digital Learning. Germany: Springer

Sejati, A, W., Yumpi, F. (2016). Pengaruh Metode Multisensori Terhadap Kemampuan Mengingat Huruf Alfabet Pada Siswa Kelompok Bermain Di Sekolah Cahaya Nurani Jember. INSIGHT ISSN: 1858-4063

Solso, R.L., Maclin, O.H., \& Maclin, M.K. 2008. Psikologi kognitif, edisi kedelapan. Jakarta: Erlangga

Sugiyono. 2009. Metode Penelitian Kuantitatif, Kualitatif dan $R \& D$. Bandung: Alfabeta

Suharnan, 2005. Psikologi Kognitif. Surabaya: Srikandi

Sujarwo, Sawi .2016. Diktat Kuliah (Psikologi Eksperimen dan Analisis Uji Komparatif). Palembang

Sujarwo, Sawi. 2017. Modul Kuliah dan Pratikum (aplikasi komputer: SPSS). Palembang

Sumiharso, R., Hasanah, H. 2017. Media Pembelajaran. Jawa Timur: Pustaka Abadi

Suryabrata, S. 2008. Psikologi Pendidikan. Jakarta: PT Raja Grafindo Persada

Susilana, R., Riyana, C. 2009. Media Pembelajaran. Bandung: CV Wacana Prima

Tan, darmawan, D, A., \& Wibowo, C. 2015. Pengaruh Permainan Kartu Kwartet Terhadap Kemampuan Mengingat Kosakata Bahasa Jepang. Psikodimensia Vol. 14 No.1 
Thalib, S, B. 2010. Psikologi Pendidikan Berbasis Analisis Empiris Aplikatif. Jakarta: Kencana

Vanesa, V. (13 april 2015) Makalah Media Audio Dan Audio Visual. Diakses Dari: vebivanesa.wordpress.com. pada tanggal 15 april 2018, jam 22.12 WIB

Walgito, B. 2002. Pengantar Psikologi Umum. Yogyakarta: Andi 